\title{
THE INFLUENCE OF THE CHEMICAL COMPOSITION OF SELECTED WASTE MATERIALS FROM THE PRODUCTION OF COPPER ON THE FINAL ENVIRONMENTAL ASSESSMENT
}

\begin{abstract}
This article presents qualitative and quantitative analysis of the waste produced by KGHM Polska Miedź. The waste has been analyzed according to its chemical composition and balanced in order to be reused and recycled. Special attention has been paid to mining industries producing the biggest amount of waste and ore enrichment businesses generating waste, which isn't reused nowadays. Laboratory reseach has been conducted on floatation waste, different kinds of slags, waste gases and water slag extracts. Attention has been drawn to the possibility of using a computer program SLAG - PROP for analyzing physicochemical features, technological features and the refining of the acquired waste. Consequently, the further way of utilization of waste has been shown. From this point of view, analyses of DTA and TG slags in an oxide coating seem especially interesting. Having a particular composition they can be successfully utillised in the refining processes of copper pyrometallyrgy.

Keywords: environmental protection, waste, recycling, KGHM, slag - prop
\end{abstract}

\section{Introduction}

Copper production process is a complex process in which obtaining blister copper containing 99.99\% pure element requires multiple processes [1-3]. Each process produces a lot of waste material, the utilization and the most efficient use can rationally manage resources to maximize profits and reduce harmful effects on the external environment. A thorough analysis of qualitative and quantitative waste and develop a suitable concept of their use and processing [4] to minimize production costs, environmental degradation, and increase profits.

\section{Analysis of the problem}

Copper production process, from extraction of the mine in the form of ore, it starts a series of processing procedures, preparing a result of copper concentrate.

After mining the ore, copper mining plants produced a number of waste. Most, as even $77 \%$ of soil material from the drill shaft, less than $12 \%$ oversize floors, scrap iron and its alloys is not more than $6.2 \%$, while dredging soil, and unsorted municipal waste related to constitute no more than $4,8 \%$. Materials formed at this stage constitute almost $80 \%$ of all mining waste.

Ore extracted from the mine has a varied content of copper, which in ores slate - carbonate varies from $0.7 \%$ to as much as $16 \% \mathrm{Cu}[5,6]$. After the concentrate process (flotation process) concentrate is obtained with a content of $25-35 \%$
$\mathrm{Cu}[7,8]$. Meanwhile, this is only the initial stage of a long journey element, where after each stage created certain waste. The most important waste ore enrichment plants is a slag shaft, which constitutes more than $47 \%$. Because it does not exceed environmental standards it can be used in the building industry. In second place is granulated slag of more than $23 \%$, which is used as an aggregate material in building hydro, and finally the material in the process of reclamation deposits. They represent a smaller part of the waste solids from the flue gas (4.3\%), slag from the power plant $(3 \%)$, lead concentrate $(2.5 \%)$, mixed and debris from demolition material (1.5\%). The sludge of metal hydroxides is about $18.2 \%$. Flotation tailings stored in the tank "Iron Bridge" to increase from year to year, an average of more than 28 million tons. Due to the existence of their valuable metal (eg. $\mathrm{Cu}$ to $0.55 \%$, zinc to $0.25 \%$ ) can be a source of further processing and obtaining a metal [9]. In addition, in light of current regulations flotation tailings can be a filler bitumen in road construction. In the process of processing copper ore should also be aware of waste in the form of gas, which include a large extent particularly harmful sulfur oxides. Sulfur dioxides $\mathrm{SO}_{2}$ are captured by the milk of lime, and the composition of this type of waste does not diverge significantly from the standard installation of flue gas.

\section{Results of research and analysis}

Betting mining and ore processing are not the only objects that generate waste products in the production processes of

\footnotetext{
* UNIVERSITY OF ZIELONA GÓRA, UL. PODGÓRNA 50, ZIELONA GÓRA

** PWSZ GŁOGÓW, PIOTRA SKARGI 5, GŁOGÓW

*** AGH UNIVERSITY OF SCIENCE AND TECHNOLOGY, MICKIEWICZA 30, KRAKÓW

**** INSTITUTE OF METALLURGY AND MATERIALS PAN, REYMONTA 25, KRAKÓW

* Corresponding author adam bk@poczta.onet.pl
} 
copper. Despite the fact that Huta Miedzi Głogów, also generates waste to a large extent they are recycled in manufacturing processes so that their number is negligible. Meanwhile, the greatest problem may constitute waste described above. The tests were subjected to various waste from flotation tailings through warehouses slag at ending gases. Attention was also drawn to the possibility of using the properties for SLAGPROP [10] allows to indicate the content of the chemical composition of various materials and their physical, chemical and refining processes pirometallurgy.

First study were subjected to flotation waste. They consist mainly oxides and metallic elements. The detailed composition of the flotation tailings was presented in the table [tab. 1]. Due to the composition of these wastes can be further processed and re-used. They are subject to recycling processes, recovery, combustion, but are also deposited in landfills, put into deep wells, or stored in areas of the plant. Accurate management of flotation tailings are presented in Table 2 [Tab. 2].

TABLE 1

The chemical composition of flotation waste

\begin{tabular}{|c|c|c|c|}
\hline \hline Type & Amount & Type & Amount \\
\hline $\mathrm{SiO}_{2}$ & $68,20 \%$ & $\mathrm{Fe} \%$ & 0,52 \\
\hline $\mathrm{CaO}$ & $6,96 \%$ & $\mathrm{Cu} \%$ & 0,17 \\
\hline $\mathrm{MgO}$ & $3,97 \%$ & $\mathrm{~Pb} \%$ & 0,05 \\
\hline $\mathrm{Al}_{2} \mathrm{O}_{3}$ & $4,63 \%$ & $\mathrm{As} \%$ & $46 \mathrm{ppm}$ \\
\hline $\mathrm{K}$ & $1,07 \%$ & $\mathrm{Ag} \%$ & $11 \mathrm{ppm}$ \\
\hline $\mathrm{Na}$ & $0,291 \%$ & $\mathrm{Hf} \%$ & $0,214 \mathrm{ppm}$ \\
\hline $\mathrm{S}$ & $0,26 \%$ & $\mathrm{Cd} \%$ & $0,17 \mathrm{ppm}$ \\
\hline $\mathrm{C}$ & $2,75 \%$ & \multicolumn{2}{l}{} \\
\cline { 2 - 3 } & \multicolumn{3}{|l}{} \\
\cline { 2 - 3 }
\end{tabular}

Since waste flotation are mainly liquid for the purposes of the redevelopment is used in the appropriate containers. With the flotation tailings recovered even $2 / 3$ of the materials. A smaller part is recycled and re-used. About $1 / 3$ of the materials is stored. As shown in Table 2, adequate protection are also subject to hazardous materials, which represent a small percentage of all waste materials.

TABLE 2

Management of waste flotation

\begin{tabular}{|c|c|c|}
\hline \hline No. & Typ of action & Amount $[\mathrm{Mg} / \mathrm{rok}]$ \\
\hline 1. & Reuse & 9,78 \\
\hline 2. & Recycling & 2019,72 \\
\hline 3. & Retrieve & 19499345,02 \\
\hline 4. & Combustion & 43,84 \\
\hline 5. & Burial in a landfill & 9875742,60 \\
\hline 6. & Introduction to deep wells & 155,95 \\
\hline 7. & Storage on site & 421,79 \\
\hline 8. & Composting & 0 \\
\hline 9. & Other & 1186438,64 \\
\hline \multicolumn{2}{|c|}{ Total weight of waste for manage } & 30565177,07 \\
\hline \multicolumn{2}{|c|}{ Total weight of waste } & 30135774,83 \\
\hline \multicolumn{2}{|c|}{ Hazardous waste } & 163498,50 \\
\hline \multicolumn{2}{|c|}{ Non-hazardous waste } \\
\hline
\end{tabular}

Another material that has been subjected to thorough study was slag shaft. In addition to the metallic elements, its main composition, they are of course oxides, including primarily silicon oxides $\mathrm{SiO}_{2}$ from $39 \%$ to $48.3 \%$. The iron oxide present in the slag shaft at about $10 \%$ does not constitute a direct threat to the environment. It should be noted, however, that the higher amounts may affect the way an environmental irritant. Finally, alumina $\mathrm{Al}_{2} \mathrm{O}_{3}$ present in an amount less than $15 \%$ is not dangerous but may also be used for the production of aluminum. From a legal point of view, it is important that the amount of lead and sulfur in the product output were a minimum. Table 3 [Tab. 3] given the chemical composition of the slag shaft.

TABLE 3

The chemical composition of the slag shaft

\begin{tabular}{|c|c|c|c|}
\hline \hline Type & Amount & Type & Amount \\
\hline $\mathrm{SiO}_{2}$ & $39-48,3 \%$ & $\mathrm{Cr}$ & $510 \mathrm{ppm}$ \\
\hline $\mathrm{CaO}$ & $15,18-20 \%$ & $\mathrm{Co}$ & $600-770 \mathrm{ppm}$ \\
\hline $\mathrm{Fe}_{2} \mathrm{O}_{3}$ & $9,3-11,3 \%$ & $\mathrm{Mo}$ & $296 \mathrm{ppm}$ \\
\hline $\mathrm{Al}_{2} \mathrm{O}_{3}$ & $11,0-13,95 \%$ & $\mathrm{Sn}$ & $18 \mathrm{ppm}$ \\
\hline $\mathrm{MgO}$ & $7,3-9,6 \%$ & $\mathrm{Ag}$ & $20-33 \mathrm{ppm}$ \\
\hline $\mathrm{S}$ & $0,17-0,8 \%$ & $\mathrm{~V}$ & $836 \mathrm{ppm}$ \\
\hline $\mathrm{Zn}$ & $0,26-0,74 \%$ & $\mathrm{As}$ & $120 \mathrm{ppm}$ \\
\hline $\mathrm{Pb}$ & $0,12-0,29 \%$ & $\mathrm{Au}$ & $2 \mathrm{ppm}$ \\
\hline $\mathrm{Cu}$ & $0,16-0,57 \%$ & $\mathrm{Cd}$ & $5 \mathrm{ppm}$ \\
\hline $\mathrm{Ni}$ & $50-60 \mathrm{ppm}$ & $\mathrm{Re}$ & $1-2 \mathrm{ppm}$ \\
\hline
\end{tabular}

It is noteworthy that in the material a small amount of precious metals such as gold $\mathrm{Ag}$ and silver $\mathrm{Au}$. But these are very minor part at the level of 33 parts per million for silver and only 2 parts per million for gold.

The last type of slag that has been subjected to the test chemical composition is blast furnace slag. According to current regulations, its composition should contain at least $2 / 3$ of the oxides of calcium, magnesium and silicon. Another material that has been tested was granulated slag. Its chemical composition is not as "rich" as slag shaft and as can be seen from Table 4 [Tab. 4] representing its chemical composition, it is present in a lesser amount of oxide.

TABLE 4

The chemical composition of granulated slag

\begin{tabular}{|c|c|c|c|}
\hline Type & Amount & Type & Amount \\
\hline $\mathrm{K}_{2} \mathrm{O}$ & $3,74 \%$ & $\mathrm{Zn}$ & $0,59 \%$ \\
\hline $\mathrm{Na}_{2} \mathrm{O}$ & $0,67 \%$ & $\mathrm{Ag}$ & $6 \mathrm{~g} / \mathrm{Mg}$ \\
\hline $\mathrm{Pb}$ & $0,89 \%$ & $\mathrm{Fe}$ & $5,39 \%$ \\
\hline $\mathrm{Cu}$ & $0,63 \%$ & $\mathrm{Ni}$ & $0,01 \%$ \\
\hline $\mathrm{As}$ & $0,007 \%$ & $\mathrm{~S}$ & $0,021 \%$ \\
\hline $\mathrm{Co}$ & $0,04 \%$ & & \\
\hline
\end{tabular}

It also is devoid of silica, which is bound within the framework of complex chemical compounds. In contrast to the slag shaft is greater in the amount of lead $\mathrm{Pb}$ at $0.89 \%$, and the same copper $\mathrm{Cu} 0.63 \%$. In the noble metal is here only silver $\mathrm{Ag}$ at a very low level, which is about 6 grams per tonne.

The last type of slag that was analyzed was a blast furnace slag. According to current regulations, its composition should contain at least $2 / 3$ of the oxides of calcium, magnesium and silicon. Analyzing the chemical composition of this material, which is presented in Table 5 [Tab. 5], it can be assumed that these values are met, as their total is $86.2 \%$. 
The chemical composition of blast furnace slag

\begin{tabular}{|c|c|c|c|}
\hline \hline Type & Amount [\%] & Type & Amount [\%] \\
\hline $\mathrm{SiO}_{2}$ & 36,9 & $\mathrm{SO}_{3}$ & 0,2 \\
\hline $\mathrm{CaO}$ & 42,8 & $\mathrm{Na}_{2} \mathrm{O}$ & 0,53 \\
\hline $\mathrm{MgO}$ & 6,5 & $\mathrm{~K}_{2} \mathrm{O}$ & 0,56 \\
\hline $\mathrm{Fe}_{2} \mathrm{O}_{3}$ & 2,5 & $\mathrm{~S}$ & 0,7 \\
\hline $\mathrm{Al}_{2} \mathrm{O}_{3}$ & 6,3 & Chlorides & 0,07 \\
\hline $\mathrm{TiO}_{2}$ & 0,67 & $\mathrm{H}_{2} \mathrm{O}$ & 0,4 \\
\hline $\mathrm{Mn}_{2} \mathrm{O}_{3}$ & 0,24 & \multicolumn{2}{l}{} \\
\cline { 1 - 3 } & \multicolumn{3}{|l}{} \\
\cline { 1 - 3 }
\end{tabular}

In addition to these compounds it contains other oxides, a relatively lack of it free of metallic elements, which when properly maintained pyrometallurgical processes, it can be assumed that as a whole go to the metal bath. It should be noted that the blast furnace slag is characterized by low natural radioactivity. The research shows that the rate of radioactivity for natural radioactive isotopes ranges from 0.53 $\mathrm{Bq}$ to $0.66 \mathrm{~Bq}$, in turn, for radium from $90.69 \mathrm{~Bq}$ to 131.51 Bq. Officially, these standards are not exceeded and do not constitute a direct threat, so they can be used in residential construction.

Another waste product were analyzed gases. Their main harmful materials are oxides of sulfur. It is these compounds pose the greatest threat to the environment being the cause of, among others, acid rain. Hence, a high priority is to install equipment for flue gas desulphurization, and ultimately the management of waste that did not have them stored in large quantities. It should also be noted that the waste gases are substantial amounts of dust, which also should not be released into the environment only by the proper equipment should be captured for the purpose of reprocessing. In the context of the development of waste dust created relevant extract water from flue gas desulphurisation plant. Their composition is mainly iron $\mathrm{Fe}$, copper $\mathrm{Cu}, \mathrm{Pb}$ Lead and arsenic As, as well as other compounds in a smaller amount, which may be on-site plants processed and used as fluxes in the pyrometallurgical processes. As can be seen the chemical composition of exhaust gases it is very diverse and includes not only oxides but different metallic elements. Hence, the formation of an aqueous extract of the flue gas desulphurisation system proved particularly beneficial.

The final analysis of the study was to undergo qualitative - quantitative water extracts from the slag. Here, an important parameter is the ability of elution of harmful substances and heavy metals from the slag. You can say that the process can be properly maintained the level of the individual compounds and the same elements to keep within the limit. It should be noted that all the compounds and the elements are at the right level, at most, the whole reaction solution beyond the standard norms. The boundaries define the reaction solution in the range of $6.5-9.0 \mathrm{pH}$, whereas in the case of the test solution had a $\mathrm{pH}$ of 11.2. It was therefore higher than the maximum value of 2,2 units.

Table 6 [Tab. 6] given chemical composition of exhaust gases, a study of the chemical composition of water extracts of slags together with the boundaries of the limit values is presented in Table 7 [Tab. 7].
The chemical composition of the waste gases

\begin{tabular}{|c|c|c|c|}
\hline Type & Amount & Type & Amount \\
\hline $\mathrm{Ca}(\mathrm{OH}) 2$ & $\begin{array}{c}25,05- \\
39,09 \%\end{array}$ & $\mathrm{Hg}$ & $\begin{array}{c}15,4- \\
16,2 \mathrm{ppm}\end{array}$ \\
\hline $\mathrm{CaSO}_{3} \cdot 0,5 \mathrm{H}_{2} \mathrm{O}$ & $\begin{array}{c}31,71- \\
42,19 \%\end{array}$ & $\mathrm{Cd}$ & $5 \mathrm{ppm}$ \\
\hline $\mathrm{CaSO}_{4} \cdot 2 \mathrm{H}_{2} \mathrm{O}$ & $\begin{array}{c}12,74- \\
14,34 \%\end{array}$ & $\mathrm{Cr}$ & $<25 \mathrm{ppm}$ \\
\hline $\mathrm{CaCO}_{3}$ & $\begin{array}{c}9,77-10,61 \\
\%\end{array}$ & Mo & $<12 \mathrm{ppm}$ \\
\hline $\mathrm{Al}_{2} \mathrm{O}_{3}$ & \begin{tabular}{c|}
$0,45-$ \\
$0,68 \%$ \\
\end{tabular} & $\mathrm{Fe}$ & $\begin{array}{c}0,24- \\
0,28 \% \\
\end{array}$ \\
\hline $\mathrm{SiO}_{2}$ & $\begin{array}{l}0,94- \\
1,15 \%\end{array}$ & $\mathrm{Sb}$ & $<0,05 \%$ \\
\hline $\mathrm{MgO}$ & $\begin{array}{c}0,77- \\
1,12 \%\end{array}$ & $\mathrm{Mn}$ & $\begin{array}{l}0,012- \\
0,013 \%\end{array}$ \\
\hline $\mathrm{CaO}$ & $\begin{array}{c}13,75- \\
18,18 \% \\
\end{array}$ & $\mathrm{C}$ & $\begin{array}{c}0,19- \\
0,20 \%\end{array}$ \\
\hline As & $\begin{array}{c}0,012- \\
0,060 \%\end{array}$ & $\mathrm{Ca}$ & $\begin{array}{c}37,3- \\
38,5 \%\end{array}$ \\
\hline $\mathrm{Zn}$ & $0,018 \%$ & $\mathrm{Cl}$ & $\begin{array}{c}0,53- \\
0,65 \%\end{array}$ \\
\hline $\mathrm{Cu}$ & $\begin{array}{c}15- \\
27 \mathrm{ppm} \\
\end{array}$ & K & $\begin{array}{c}0,034- \\
0,046 \%\end{array}$ \\
\hline $\mathrm{Ni}$ & $<12 \mathrm{ppm}$ & $\mathrm{Na}$ & $\begin{array}{c}0,071- \\
0,085 \%\end{array}$ \\
\hline $\mathrm{Pb}$ & $\begin{array}{c}0,019- \\
0,024 \text { ppm }\end{array}$ & $\begin{array}{l}\text { Loss on } \\
\text { ignition }\end{array}$ & $\begin{array}{c}12,10- \\
17,40 \%\end{array}$ \\
\hline
\end{tabular}

The possibility of using waste materials in the production of copper are determined by their physical, chemical, and finally technology. Due to the wide variety of compounds and elements with whom you can meet in the waste tailings, slag, or water extracts may be applicable. Especially valuable are the product of blast furnace slag, which can produce blast furnace cement, used for ballast roads and stadiums, they are also used in production of clinker or slag wool. A particularly interesting use of slag is the possibility to use them directly in the mills during the production of metals and alloys. With a suitable composition of the slag and possibly additional ingredients slag is an excellent means of pyrometallurgical refining processes. Floating on the surface of the liquid metal bath can be observed not only the passage of non-metallic inclusions from the liquid metal to slag in accordance with the law of Nernst, but also the chemical interactions between the layer of slag and liquid metal, preferably affecting the composition of the starting liquid metal.

We must also remember that the slag in metallurgical processes fully a crucial role. In the case of such processes is the removal of harmful admixtures and impurities in the melt, the protection of the mirror liquid metal from the influence of the atmosphere, reduces the adverse effects on the lining of the furnace, and finally maintaining the reaction products occurring in the melt. However, all of these effects are dependent on the physicochemical properties of slags, particularly in the oxide matrix. The example can be too low viscosity of the slag, which would imply that the process will be melted in a furnace in the vicinity of the wall, exposing the liquid metal mirror, as we know, this will avoid exposing the metal to the negative influence of the external atmosphere. On the other 
hand too high viscosity of the material will hinder the passage of inclusions and impurities into the slag, thereby refining its effects will be much worse. In addition to the viscosity are also significantly different properties even as the melting point, wettability, surface tension or electrical conductivity. Interestingly, in this context it represents a computer program SLAG - PROP to evaluate the physicochemical, refining and technology properties of slag. Such a computer analysis of the properties of slag begins with selecting the analysis, as shown in Figure 1 [Fig. 1].

TABLE 7

The chemical composition of water extracts of slags and their limits

\begin{tabular}{|c|c|c|c|c|}
\hline No. & Type & $\begin{array}{c}\text { Unit of } \\
\text { measure }\end{array}$ & Test result & The limit value \\
\hline 1. & Phosphorus & $\mathrm{mg} \mathrm{P} / 1$ & 0,12 & 3 \\
\hline 2. & $\begin{array}{c}\text { Ammonia } \\
\text { nitrogen }\end{array}$ & $\mathrm{mg} \mathrm{N}_{\mathrm{NH} 4} / \mathrm{l}$ & $<0,05$ & 10 \\
\hline 3. & Sodium & $\mathrm{mg} \mathrm{Na} / 1$ & 19 & 800 \\
\hline 4. & Potassium & $\mathrm{mg} \mathrm{K} / 1$ & 2,5 & 80 \\
\hline 5. & Iron & $\mathrm{mg} \mathrm{Fe} / 1$ & $<0,04$ & 10 \\
\hline 6. & Antimony & $\mathrm{mg} \mathrm{Sb} / 1$ & 0,00007 & 0,3 \\
\hline 7. & Arsenic & $\mathrm{mg} \mathrm{As} / 1$ & 0,00041 & 0,1 \\
\hline 8. & Barium & $\mathrm{mg} \mathrm{Ba} / \mathrm{l}$ & 0,024 & 2 \\
\hline 9. & Zinc & $\mathrm{mg} \mathrm{Zn/1}$ & 0,00464 & 2 \\
\hline 10. & Chromium & $\mathrm{mg} \mathrm{Cr} / 1$ & 0,0026 & 0,5 \\
\hline 11. & Cadmium & $\mathrm{mg} \mathrm{Cd} / 1$ & $2 \mathrm{E}-06$ & no requirements \\
\hline 12. & Cobalt & $\mathrm{mg} \mathrm{Co} / 1$ & 0,00013 & 1 \\
\hline 13. & Copper & $\mathrm{mg} \mathrm{Cu} / \mathrm{l}$ & 0,0012 & 0,5 \\
\hline 14. & Manganese & $\mathrm{mg} \mathrm{Mn} / 1$ & 0,00015 & no requirements \\
\hline 15. & Molybdenum & $\mathrm{mg} \mathrm{Mo} / \mathrm{l}$ & 0,00092 & 1 \\
\hline 16. & Nickel & $\mathrm{mg} \mathrm{Ni} / 1$ & 0,00042 & 0,5 \\
\hline 17. & Lead & $\mathrm{mg} \mathrm{Pb} / 1$ & 0,00005 & 0,5 \\
\hline 18. & Mercury & $\mathrm{mg} \mathrm{Hg} / \mathrm{l}$ & 0,00128 & 0,03 \\
\hline 19. & Selenium & $\mathrm{mg} \mathrm{Se} / 1$ & 0,0031 & 1 \\
\hline 20. & Thallium & $\mathrm{mg} \mathrm{Tl} / 1$ & 0,00001 & 1 \\
\hline 21. & Vanadium & $\mathrm{mg} \mathrm{V} / \mathrm{l}$ & 0,0067 & 2 \\
\hline \multicolumn{2}{|r|}{ Reaction } & $\mathrm{pH}$ & 11,2 & $6,5-9,0$ \\
\hline \multicolumn{2}{|r|}{ Chloride } & $\mathrm{mgCl} / 1$ & 2,04 & 1000 \\
\hline \multicolumn{2}{|c|}{ Sulphureous } & $\mathrm{mgSo} 4 / 1$ & 102,23 & 500 \\
\hline \multicolumn{2}{|c|}{ Solutes Total } & $\mathrm{Mg} / 1$ & 360 & no requirements \\
\hline
\end{tabular}

\section{Select the research direction of the properties of slags.}
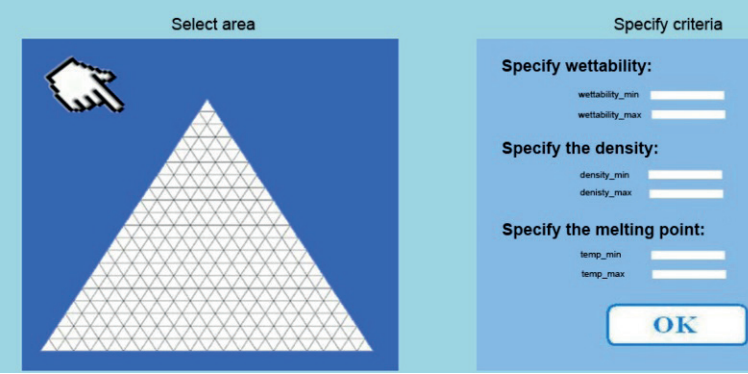

Fig. 1. The choice of the analysis of the properties of slags

After choosing "select area" user selects the slag, which would be analyzed. In the case of an advanced version, he may select the kind of atmosphere, or the type of metal, which will then give refining. After selecting the parameters of the initial user is presented Gibbs triangle, where he may intuitively indicate the area mixes that interested him. The system itself is also equipped with a calculator, which allows quickly to find an area with a specific chemical composition.

System and a special search area is presented in Figure 2 [Fig. 2]. After selecting interesting user area are presented to him detailed information about the properties of a mixture of slag.
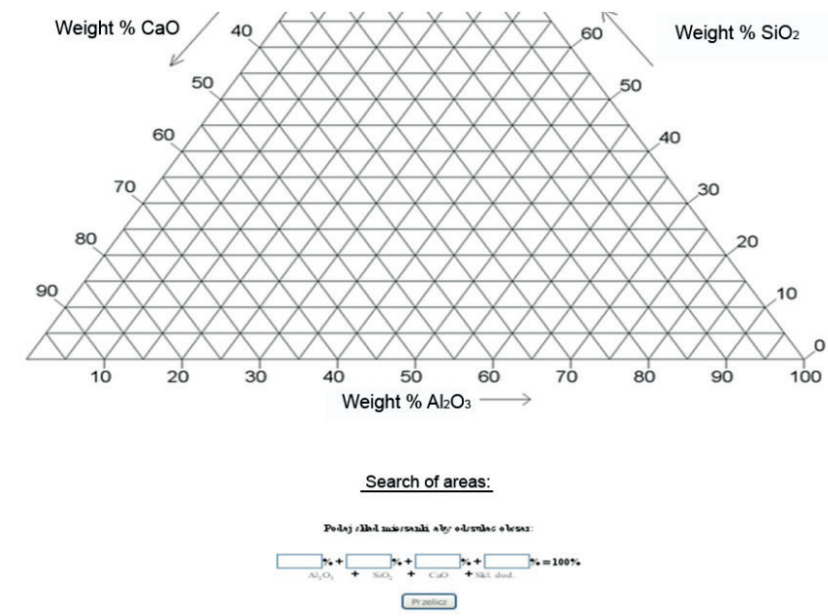

Fig. 2. Gibbs triangle with searchable areas

It should also be noted that the system has the ability to double-track action. By selecting "Enter the criteria," the user can search the database looking for the best composition of the mixture of slag for him interesting properties. The user indicates his choice property eg. Viscosity, and then entered limit values, which is the minimum and the maximum. After approval of his choice program performs filtering database and then displays his list of areas that meet the criteria specified by the user. With the acquisition of such rapid information, you can not conduct additional research and painstaking research to obtain information on the suitability of the product constituting the waste slag production process for a particular purpose, provided knowledge of the relevant parameters of the application. Meanwhile, in the figure below 3 [Fig. 3] shows the result obtained by the user when selecting an area marked number 362. In this case the area selected is a blend of slag composition: $\mathrm{Al}_{2} \mathrm{O}_{3}(10-15 \%), \mathrm{CaO}(30-35 \%)$ and $\mathrm{SiO}_{2}(50$ $-55 \%)$.

The proposed program Slag - prop also has another very important environmental aspect. A huge database, which has in the context of physical, chemical, refining, and even technology properties allows the user to quickly reach the interesting information. At this point, there is no need for additional, often painstaking research and the result obtained in a few seconds. It should be noted that any conduct of the study involves not only the use of energy or other media, but also results in waste generation as the samples used, gases, dusts, etc. The database is detrimental fact is eliminated.

Thanks to the program, following the process of refining the particular metal, you can directly reach the best available and well-established coating extraction matrix oxide. The program, which represents a broad properties of mixtures of slag used in the vast majority of ingredients are 
not characterized by a high toxicity in the process of refining. Here the user to deal with 6 different components which are oxides, including the basic layout of the base $\mathrm{Al} 2 \mathrm{O} 3-\mathrm{CaO}$ $\mathrm{SiO} 2$, then the two salts, the type of chlorides, eg. $\mathrm{NaCl}$, and three types of fluoride, which do not pose a health risk, while maintaining proper precautions.

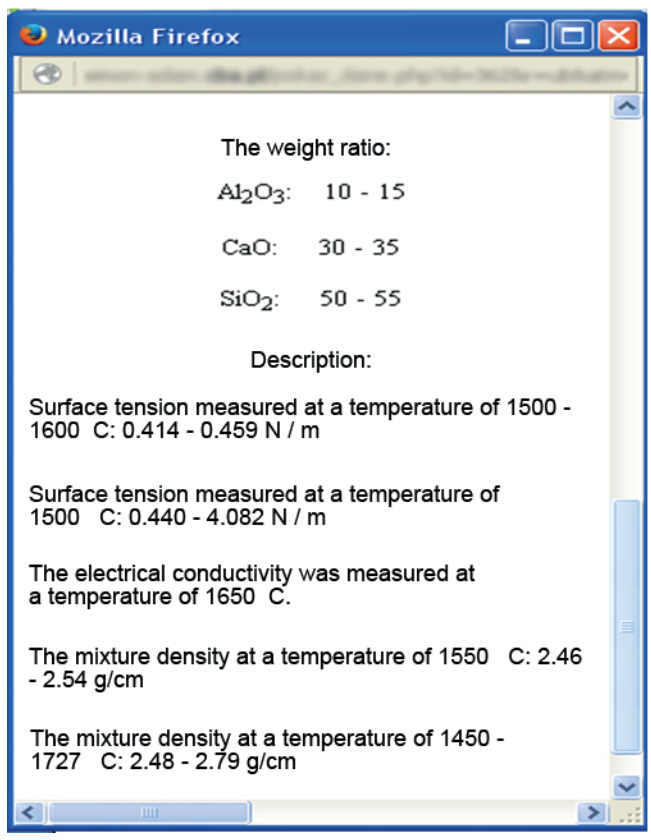

Fig. 3. Description of the area indicated by the user in the SLAG PROP

\section{Summary}

In conclusion it is worth paying attention to is that the structure of expenditures related to environmental considerations absorbs most of the costs for the storage of waste $(84.2 \%)$. In second place is a dump water from the sediment $(9.5 \%)$, while emissions into the air is a cost of less than $5 \%$. Absorbs about $1.5 \%$ of total wastewater discharge and water intake. On this basis, you can definitely say that the waste should be in up to a large extent be reprocessed and used. This not only reduce the costs of storage, but these treatments will have a positive influence on the management of environmental resources. KGHM is a large enterprise, in which the rational management of resources, including waste should be a model for imitation. In the production processes of copper and other metals or compounds of KGHM, the largest amount of waste produced in the mineral material of which include natural gas resulting from drilling wells, oversize material from the floor, and scrap iron. Particularly large area distortion is observed in the case of open cast mines. On the other hand, in the case of ore enrichment plants you can meet with waste materials such as slag hole, granular, solid waste after the desulphurization of gases, as well as slags from power plants, lead concentrates, and finally sludge metal hydroxides. The amount of dangerous substances is relatively low, while the slags encountered large quantities of oxides of calcium, magnesium and silicon.
The company KGHM undoubtedly introduces a large amount of pollutants into the environment. The process of mining is a major interference with the natural ecosystem, which is gradually changed. Note, however, that the production with which we are dealing in the company is producing at a very high level, which in the case of some products it belongs to the world leaders. Such production can not be deprived of the price you have to pay not only in the amount of environmental fees, but also the prices for the same high exploitation of nature. Continuous development of the company, however, allows to improve processes and gradually reduce pollution of the environment. As indicated by studies [11-13] of 80 years - the last century through appropriate concepts, improvements and changes to a large extent managed to reduce the amount of emissions particularly sulfur oxides, and particulate matter and lead. Emissions to the environment of metals such as copper, cadmium, and arsenic has large decrease. Conduct further work related to the monitoring and analysis of quality - quantitative waste, as well as the development of new concept will allow for even better environmental effects.

\section{Acknowledgements}

This project was supported by the National Center for Research and Development under Grant No. PBS3/A5/45/2015 (PBS3/244 864/PP/MMB).

\section{REFERENCES}

[1] W.G. Davenport, E. H. Portelpoeg, Flesh smelting, analysis, control and optimization, 1987 Pergamon Press, Toronto.

[2] M. Kucharski, T. Sak, P. Madej, M. Wędrychowicz, W. Mróz , Metall. Mat. Trans. B. 45 (2), 590-602 (2014).

[3] I. Kurytnik, B. R. Nussupbekov, A. K. Khassenov, D. Zh. Karabekova, Arch. Metall. Mater. 60 (4), 2549-2551 (2013).

[4] A.W. Bydałek, A. Bydałek, W. Wołczyński, S. Biernat, Arch. Metall. Mater. 60 (1), 319 - 322 (2015).

[5] S.C. Barlett, H. Burgess, B. Dajmanović, R.M. Gowans, C.R. Lattanazi, Technical Report on the copper-silver production operations of KGHM Polska Miedź S.A. in the LegnicaGłogów Copper Belt area of southwestern Poland, 2013 Bay Street, Toronto.

[6] B. Onderka, D. Jendrzejczyk-Handzlik, K. Fitzner, Arch. Metall. Mater. 58 (2), 51-57 (2013).

[7] M. Kucharski, Pirometalurgia miedzi, 2003 Uczel. Wydawn. Nauk. AGH, Kraków.

[8] J. Kazibut, A. Węglarz, C. Malinowski, S. Małecki, Acta Metall. Slov. 7, 83-89 ( 2001).

[9] A. Duczmal - Czernikiewicz, J. Suchan, K. Zielnica, Przegl. Geolog. 55 (4), 285-289 (2007).

[10] S. Biernat, A.W. Bydałek, Arch. Foun. Eng. 9 (3), 9 - 12 (2009).

[11] Ł. Strzelec, W. Niedźwiecka, Environmental Medicine 15 (2), $21-31$ (2012).

[12] B. Dębski, A. Olecka, K. Bebkiewicz, I. Kargulewicz, J. Rutkowski, D. Zasina, M. Zimakowska - Laskowska, M. Żaczek, National balance of emissions of $\mathrm{SO}_{2}, \mathrm{NOx}, \mathrm{CO}$, 
NH3, NMLZO , particulates, heavy metals and TZO in a classification SNAP and NFR, 2015 Wydawn. KOBiZE, Warszawa.
[13] R. Sadlok, A. Graboś, S. Żymankowska - Kumon, J. Sadlok, R. Sadlok, Preventing low emissions in a compact residential development, 2014 Wydawn. Helios, Bochnia. 